\title{
The Oxford Dodo. Seeing more than ever before: X- ray micro-CT scanning, specimen acquisition and provenance
}

\author{
J. M. Warnett , Mark A. Williams, Paul F. Wilson \& M. Paul Smith
}

To cite this article: J. M. Warnett, Mark A. Williams , Paul F. Wilson \& M. Paul Smith (2020): The Oxford Dodo. Seeing more than ever before: X-ray micro-CT scanning, specimen acquisition and provenance, Historical Biology, DOI: 10.1080/08912963.2020.1782396

To link to this article: https://doi.org/10.1080/08912963.2020.1782396
(c) 2020 The Author(s). Published by Informa UK Limited, trading as Taylor \& Francis Group.

\section{$+$}

View supplementary material ¿

曲 Published online: 12 Jul 2020.

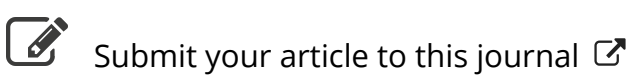

Џll Article views: 1002

Q View related articles ¿

View Crossmark data $\nearrow$ 


\title{
The Oxford Dodo. Seeing more than ever before: X-ray micro-CT scanning, specimen acquisition and provenance
}

\author{
J. M. Warnett $\mathbb{D}^{\mathrm{a}}$, Mark A. Williams $\mathbb{( \mathbb { D }}^{\mathrm{a}}$, Paul F. Wilson $\mathbb{D}^{\mathrm{a}}$ and M. Paul Smith $\mathbb{( D}^{\mathrm{b}}$ \\ ${ }^{a}$ WMG, University of Warwick, Coventry, UK; ${ }^{b}$ Oxford University Museum of Natural History, Oxford, UK
}

\begin{abstract}
The Oxford Dodo (Raphus cucullatus) has been in the collections of the University of Oxford since 1683, first in the Ashmolean Museum and latterly in Oxford University Museum of Natural History. Prior to this the specimen was part of the collections of the Tradescants, father and son, and likely acquired between 1634 and 1656, in the Musæum Tradescantianum in what is now Vauxhall, south London. It has been thought probable that this specimen was once the live bird recorded in London by Sir Hamon L'Estrange in around 1638 , but X-ray CT scanning of the skull for anatomical investigation has cast doubt on the provenance of the Oxford Dodo. The 3D visualisation revealed 115 metal particles embedded within the bone of the skull, concentrated in the left side of the skull. All but five of the particles are less than $1 \mathrm{~mm}$ in diameter and their location leads to the conclusion that they represent lead shot consistent with the bird being shot from the rear right of the head, perhaps with a ventral component. This forensic discovery leaves the provenance of the Oxford specimen uncertain but illustrates the value of non-invasive visualisation techniques in determining the potentially complex histories of unique museum objects.
\end{abstract}

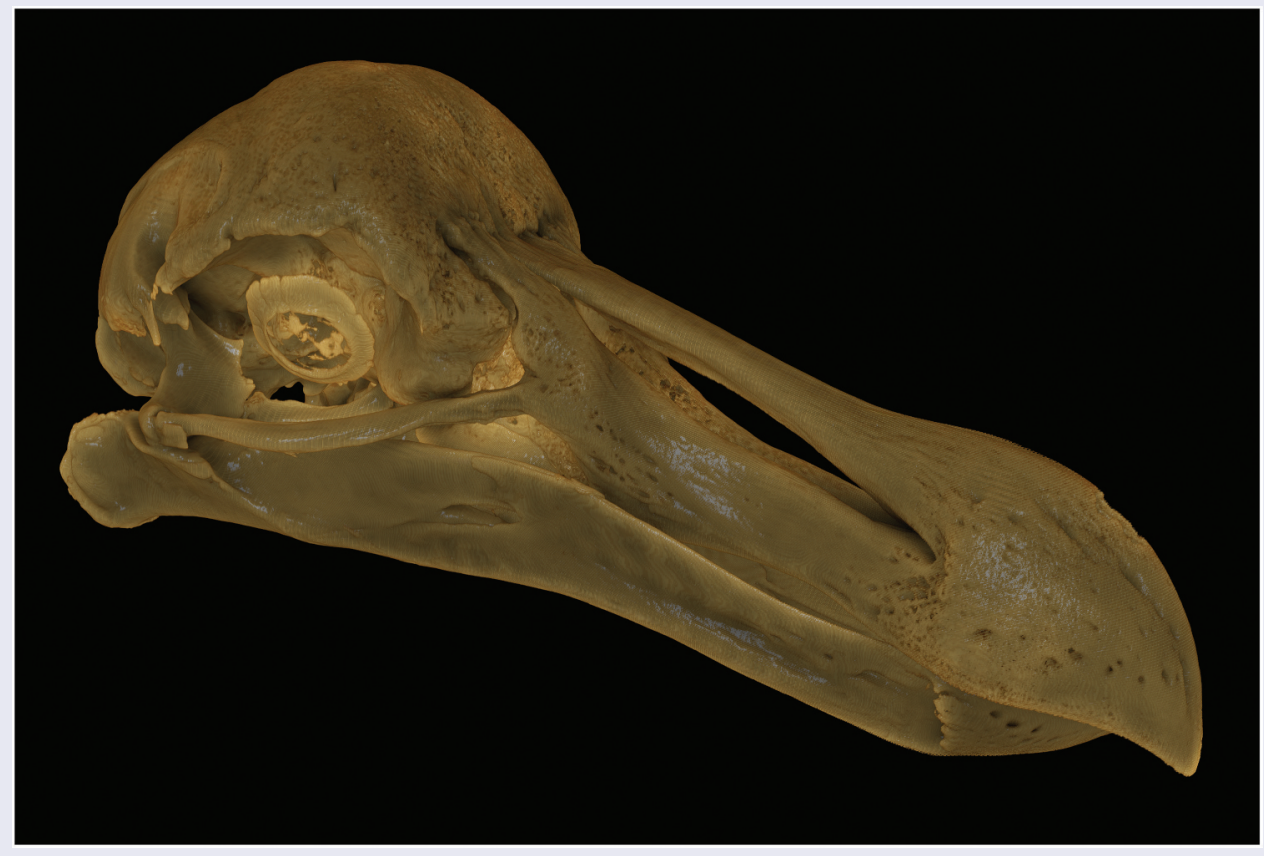

\section{ARTICLE HISTORY}

Received 15 April 2020

Accepted 9 June 2020

\section{KEYWORDS}

Mauritius; Columbidae; John Tradescant; Elias Ashmole; visualisation; X-ray CT
'There they always used to discharge their birding pieces'

William Shakespeare, 1602, The Merry Wives of Windsor

\section{Introduction}

The Dodo is an extraordinary species of extinct bird that has the capacity to provide insight to a wide range of scientific and cultural enquiry, extending from the nature of island speciation and the evolutionary origin of flightlessness to the exploration of the Indian Ocean by western European nations and the establishment of global trade routes, before becoming a literary icon via Lewis Carroll, Hilaire Belloc and others. Raphus cucullatus (Linnaeus 1758) was first documented in 1598 on the island of Mauritius by those aboard ships of the second Dutch expedition to what is now Indonesia, led by Admiral Jacob Corneliszoon Van Neck, although the island had been discovered earlier in the 1500s by the Portuguese (Strickland 1848; Hume 2006). Extensive histories of those early encounters with Dodos have been provided by Strickland (1848), Hume (2006), Parish (2013), Hume and Winters (2016) and Nowak-Kemp and Hume (2017a). 
By the 1690s, and probably earlier, the Dodo was extinct giving it the unfortunate distinction of having one of the shortest intervals between discovery and extinction of any species, and it has in consequence become emblematic of anthropogenic extinction. There has been some debate over the extinction date of the species (Jackson 2013; Roberts 2013; Cheke 2015; Cheke and Parish 2020), and that debate revolves around the veracity of a report of Dodos in the journal of Benjamin Harry who visited Mauritius in 1681 (Strickland 1848; Jackson 2013). In contrast, Cheke (2015) favoured a last sighting on mainland Mauritius in the 1640s and on an offshore refuge in 1662; a full chronology of observations was provided by Cheke and Parish (2020). Notwithstanding this debate, by 1693 Legaut noted that a range of birds on Mauritius that were previously common was becoming rare and made no mention at all of the presence of Dodos, which was presumably extinct by then (Strickland 1848). As Cheke and Parish (2020) noted, it is only when some food animals became scarce in the 1690s that visitors began to consider the question of extinction, with the absence of Dodos first recorded by Morel (1778).

Very few specimens of Dodos were exported from Mauritius during the seventeenth century. It is known that a living specimen was illustrated by Ustad Mansūr in the court of the Mogul emperor Jahāngīr in Surat, India between 1624 and 1627 (Ivanov 1958; Das 1973; Hume 2006; Parish 2013), which may have been one of the two Dodos observed by Peter Mundy in the menagerie of Jahāngīr in Surat in 1628 (Das 1973; Hume 2006; Parish 2013). The last record of a captive Dodo was of one taken in 1647 by Willem Verstegen of the Dutch East India Company to their trading post in Nagasaki. The warehouse journal notes its receipt and transfer for the perusal of the daimyō (lord) of Hakata, but its subsequent fate is unknown (Winters and Hume 2015). There is physical or reliable indirect evidence for as few as six Dodo specimens reaching Europe derived from living, rather than sub-fossil, specimens:

(1) A skull in the collections of Statens Naturhistoriske Museum, Copenhagen, possibly from the collection of the Dutch collector Bernardus Paludanus (Hume 2006; but see Parish (2013) for an alternative view).

(2) An illustration of a taxidermy specimen with signs of decay from as early as 1600 within the collections of the Emperor Rudolf II in Prague (Hume 2006).

(3) A possible albid Dodo, also from the collections of Rudolf II, as depicted by Roelandt Savery and subsequently copied by other artists (Hume and Cheke 2004). The albid appearance may be artistic licence (Den Hengst 2003; Parish 2013).

(4) The caption to a pen and ink watercolour by Adrienne Pieterszoon Van De Venne in 1626 mentions a Dodo as having been present alive in Amsterdam, and this may be the specimen illustrated multiple times by Roelandt Savery in his later paintings (Hume 2006).

(5) A Dodo foot, now lost, was present in the Royal Society collections in London in the seventeenth century and then passed to the British Museum (Strickland 1848). The last dated photograph of the foot was taken in 1907 by Benjamin Stone (Parish 2013), but there is no record of it having been seen since that date.

(6) The best-preserved $17^{\text {th }}$ century Dodo remains, globally, are those of the Oxford Dodo, which today consist of a skull with preserved skin, sclerotic rings and some feathers together with a dissected foot, and these are the subject of this paper. In addition, there is indirect documentary evidence of a Dodo leg having once been present in the collection of Petrus Pawius in Leiden (Clusius 1605) and possibly three additional specimens in the Anatomy School of the
University of Oxford (Boas 1935; Parish 2013; Nowak-Kemp and Hume 2017b), though it is not at all certain that these were Dodos (Hume 2006).

There is reliable evidence for only five live Dodos leaving Mauritius, of which two are the Indian specimens noted above and one is the Japanese bird. Only two live Dodos were recorded in Europe - the Amsterdam specimen illustrated by Van De Venne and perhaps Savery, and a live specimen in London. The latter was recorded by the politician and retired member of parliament Sir Hamon L'Estrange:

\begin{abstract}
About 1638, as I walked London streets, I saw the picture of a strange fowle hong out upon a cloth ... and myselfe with one or two more then in company went in to see it. It was kept in a chamber, and was a great fowle somewhat bigger than the largest Turky Cock, and so legged and footed, but stouter and thicker and of a more erect shape, coloured before like the breast of a yong cock fesan, and on the back of dunn or deare coulour. The keeper called it a Dodo, and in the ende of a chymney in the chamber there lay a heape of large pebble stones, whereof hee gave it many in our sight, some as bigg as nutmegs, and the keeper told us shee eats them (conducing to digestion), and though I remember not how farr the keeper was questioned therein, yet I am confident that afterwards shee cast them all againe. (British Library MS Sloane 1839, fol.54r; Wilkin 1835-1836; Strickland 1848).
\end{abstract}

The L'Estrange specimen may represent a seventh specimen recorded to have entered Europe from Mauritius or it may be the same one that later entered the Tradescant collection.

\section{Provenance of the Oxford Dodo}

The specimen currently housed in Oxford University Museum of Natural History (OUMNH.ZC.11605) arrived in Oxford in March 1683 as part of the Ashmole bequest to the University of Oxford. In 1675, Elias Ashmole had approached the university with a view to gifting his collection of books and artefacts, on the condition that it build a museum to house the collection (now the History of Science Museum on Broad Street). The specimen is recorded in the Index Aviū compiled by Lhwyd (1695-1696) and initially was preserved as a whole bird, probably as a flat, cabinet skin (Nowak-Kemp and Hume 2017a). However, by 1755 the specimen had decayed to such an extent that part of it had to be destroyed (Nowak-Kemp and Hume 2017a). Only the head and both legs could be saved at that point, and these were recorded as separate items in the Liber Dōni Principalis Collegii Aenei Nasi catalogue of 1756 (Nowak-Kemp and Hume 2017a). The head and one surviving foot were the subjects of the detailed anatomical description of Melville (1848).

Ashmole's founding collection had comprised books, medals and coins together with the contents of the Musæum Tradescantianum, also known as Tradescant's Ark. The latter was a collection assembled as a cabinet of curiosity by John Tradescant and his son, John the younger, who as naturalists, collectors and garden designers to George Villiers, 1st Duke of Buckingham, and subsequently to Charles I, had acquired material from Europe, Asia, Africa and the new colonies in North America. In the late 1620s, Tradescant the elder opened the collection to the public in their house in South Lambeth, now Vauxhall, London, thereby creating the first public museum in Britain. The Dodo is documented in the catalogue of 1656, the Muscum Tradescantianum: Or, A collection of rarities preserved at South-Lambeth neer London by John Tradescant, where it is recorded as 'Dodar, from the Island Mauritius; it is not able to flie being so big' (Tradescant 1656, p. 4). Significantly, it is recorded in the catalogue under 'Some kindes of Birds with their Egges, Beaks, Feathers, Clawes, and 
Spurres', and under the subheading of 'Whole Birds', confirming that the Tradescant specimen was a complete Dodo.

The precise timing of entry to the Tradescant collection prior to this date and the route of acquisition is, however, less clear and any inference is based on an absence of mention rather than a presence of evidence. Peter Mundy, who had seen the Dodos in the emperor Jahāngīr's palace in Surat in 1628 (see above), visited the Musæum Tradescantianum in 1634 and described it:

\begin{abstract}
I was invited by Mr. Thomas Barlow (whoe went into India with my Lord of Denbigh and returned with us on the Mary) to view some rarities at John Tradescans, soe went with him and one freind more, where wee spent the whole day in peruseings, and that superficially, such as hee had gathered together, as beasts, fowle, fishes, serpents, wormes (reall although dead and dryed), pretious stones and other Armes, Coines, shells, fethers, etts.... whereof some that I had not seene elsewhere but in India, being supplied by Noblemen, Gentlemen, Sea Commaunders, etts. with such Toyes [curiosities] as they could bringe or procure from other parts. (Temple 1919)
\end{abstract}

Given that Mundy had seen Dodos in Surat just six years earlier he would surely have mentioned the presence of one in the Tradescants' collection, so it seems probable that the Dodo was not in the collection in 1634. A number of other visitors described visits to the collections between 1634 and the publication of the catalogue in 1656 (see Nowak-Kemp and Hume 2017a, for details) but none of them mention a Dodo.

The apparent absence of a Dodo in the Musæum Tradescantianum in 1634 and the timing of the account of a living specimen in London in around 1638 have led to a view that the two records probably refer to the same bird:

I shall speak further of these hereafter, and will at present only remark that this is in all probability the same individual which was exhibited in London, and which Lestrange described in 1638 (Strickland 1848, p. 23)

It is probable, but not certain, that the Dodo seen by the English Theologian Sir Hamon L'Estrange in a London shop ... was eventually exhibited in the museum of John Tradescant, naturalist and gardener to Charles II, in Lambeth, London (Hume 2006)

L'Estrange's bird is by far the best candidate for the origin of the Tradescant Dodo (Nowak-Kemp and Hume 2017a)
Recent X-ray CT scanning of the Oxford Dodo, initially to elucidate the cranial anatomy, has cast some doubt on this linkage.

\section{Materials and methods}

The Oxford Dodo specimen was transferred to the WMG laboratories at the University of Warwick, UK, to perform non-destructive X-ray Computed Tomography (CT) using a Zeiss Versa 520 (Figure 1). The Dodo head was carefully packed within a large plastic cylinder using foam to support the specimen and to keep it in position. The mounted specimen was then placed on a rotating turntable between the X-ray source (Figure 1, left) and a detector screen (Figure 1, right) that is $2048 \times 2048$ pixels wide. With the X-rays on, the detector captures an absorption projection as the X-rays pass through the specimen. Its appearance is the same as standard medical-CT where different grey-scales within the image show varying depths and/or densities of materials. In each full rotation, 3200 projections were collected that were then used to reconstruct a $3 \mathrm{D}$ representation of the specimen, which comprises a stack of $2 \mathrm{D}$ image slices.

Given this rare opportunity to scan the specimen, and to obviate the need for repeated scanning in the future, the specimen was scanned at a high magnification with the individual scans then stitched together digitally. First, it was stitched once horizontally in a single scan (often referred to as wide field), and then stitched another six times vertically to capture the entire specimen at a $29 \mu \mathrm{m}$ pixel resolution given the limitation of the detector size. This results in a $3800 \times 3800 \times 11,300$ volume that with current computing power is too large to manipulate easily. The visualisations used in this paper were created from a sub-sampled volume that is $1000 \times 1000 \times 3000$, giving a $110 \mu \mathrm{m}$ resolution. All dimensions and measurements used below were, however, obtained from the high-resolution scan data.

\section{Anatomical observations}

The grey levels within the images (Figure 2, 3) clearly identify two different materials in the $2 \mathrm{D}$ image slices of the

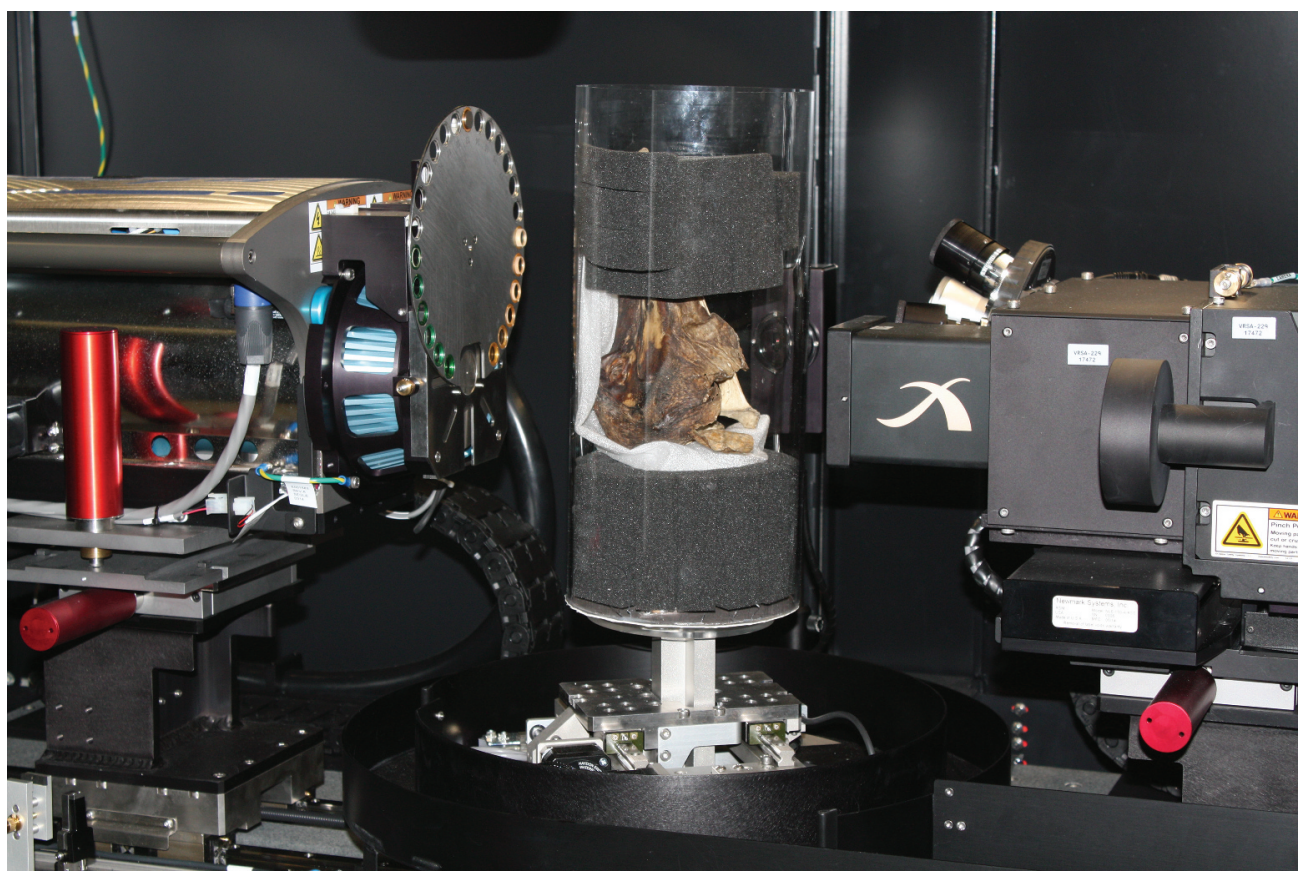

Figure 1. Setup of the dodo specimen within the Zeiss Versa 520 X-ray CT scanner. 


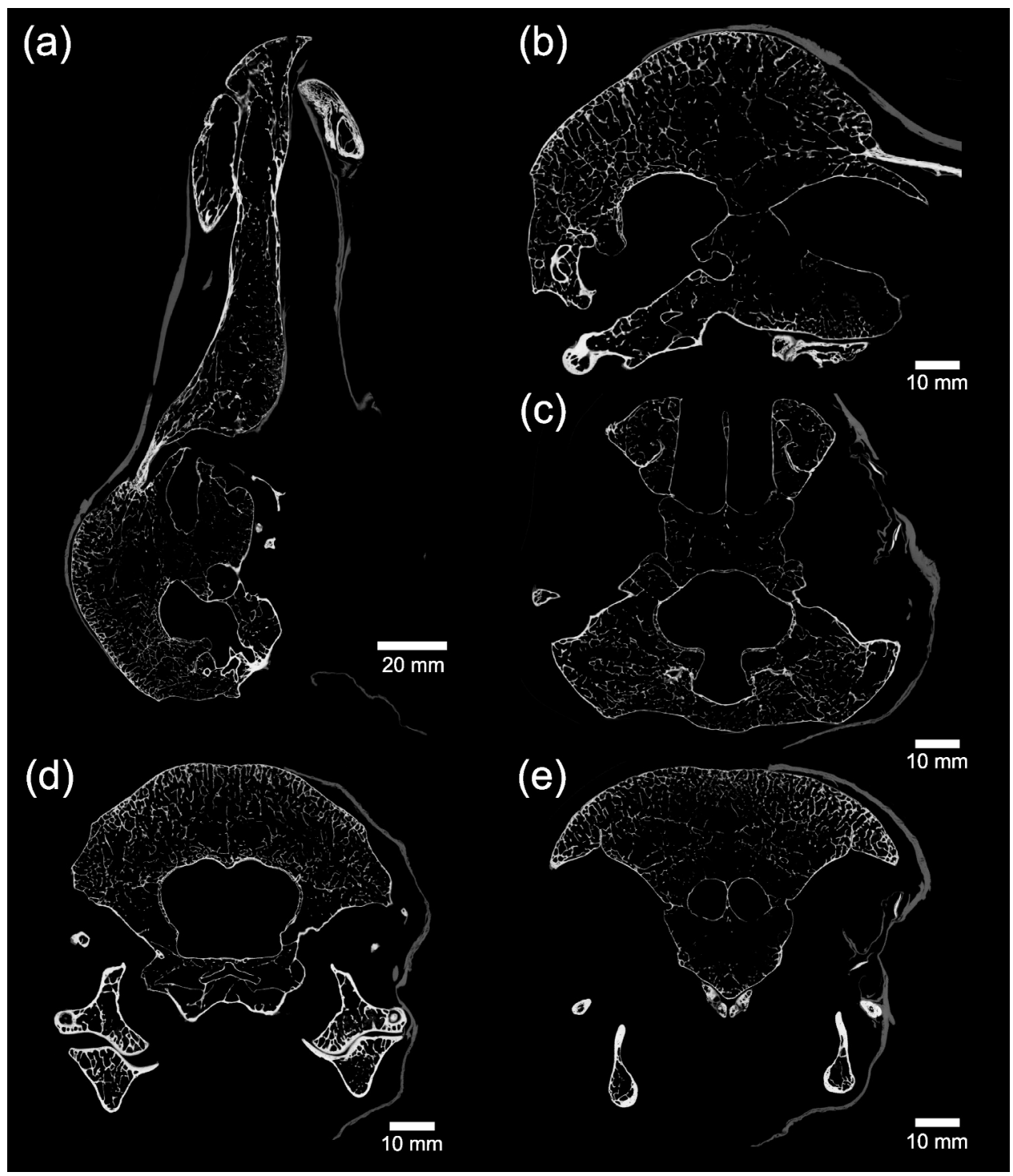

Figure 2. Ortho slices through the Oxford Dodo, Raphus cucullatus (Linnaeus, 1758) (OUMNH.ZC.11605), derived by X-ray CT scanning. The bright values indicate bone and the grey values the skin preserved on the right-hand side of the skull. (a) Sagittal section through the entire specimen; (b) Magnified view of sagittal section to show the structure of the trabecular bone; (c) Transverse section aligned through the eye region of the specimen. The sclerotic ring is visible within the skin in the top right of the image; (d) Coronal section through the posterior of the skull showing the cranial cavity; (e) Coronal section of the anterior part of the skull showing the positioning of the sclerotic ring.

reconstructed volume in the sagittal and transverse planes, with bone being the brighter white (higher X-ray opacity) and skin preserved on the right side of the skull represented by the less dense grey surround.

The most striking feature of the ortho slices through the specimen is the presence of the extensive trabeculae, both in terms of density and number. Owen (1867) presented a plate of a sectioned Dodo cranium showing the trabeculae, but they can now be examined in $3 \mathrm{D}$ throughout the skull. The skin still encapsulates large amounts of the beak, particularly the lower jaw, and around the sclerotic ring of the eye. Some large gaps between the skin and cranium exist, possibly where skin was peeled away after wetting and then dried again by Cuvier (Parish 2013) and then again by Melville (1848) for their anatomical studies. In contrast, the skin around the lower jaw seems to be largely untouched.

One interesting feature that is yet to be explained is a hardening of the skin along the upper edge of the beak towards the back of the mandible (Figure 3). This feature is $3.5 \mathrm{~mm}$ in length and of conspicuously higher X-ray opacity compared with the surrounding skin, suggesting that it is calcified. The patch of tissue is not visually differentiated on the specimen itself, but a scan of the skin that was removed from the opposite side of the skull by Melville (1848) revealed a similar structure in an identical location on the opposite side of the beak, suggesting that it is anatomical rather than pathological or artefactual.

The power of the CT methodology lies in the subsequent possibilities for visualisation of the scanned object. The generated ortho slices form a stack, which therefore has $3 \mathrm{D}$ form, and enables the non-intrusive observation and measurement of internal features even on a unique four-hundred-year-old museum specimen. This is a significant advance over the illustrative methods available to earlier studies of the Oxford Dodo, and the datasets are available to researchers for future research (MorphoSource, Identifier: 28,110; Media: M55320, uploaded January 2020). 


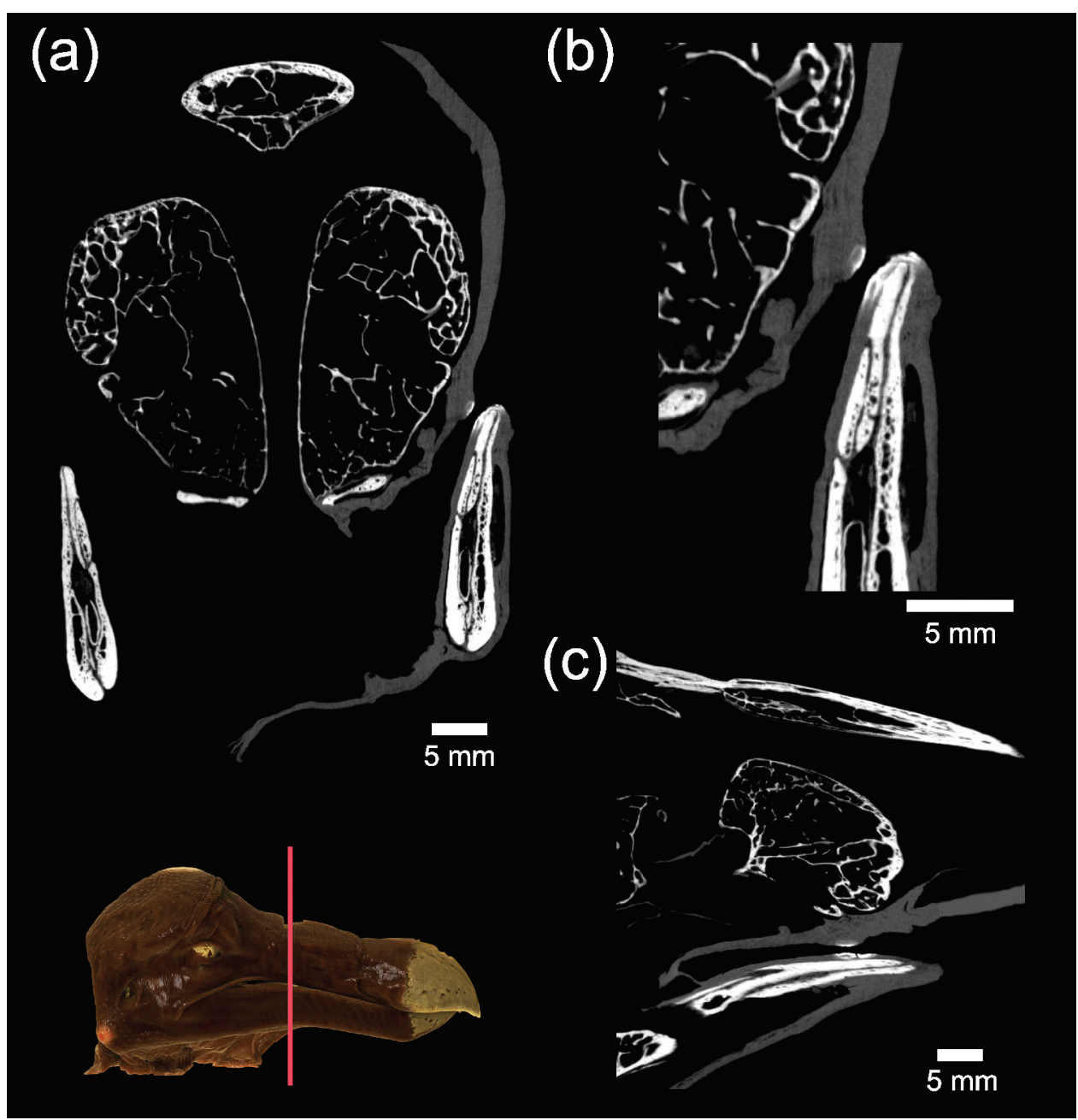

Figure 3. Ortho slices through the Oxford Dodo derived by X-ray CT scanning together with rendered 3D model (inset) showing position of coronal section. (a) Coronal section through the rostrum showing calcified tissue within the skin. Magnified views of this mineralised soft tissue are shown in (b) coronal section and (c) transverse section. Calcified tissue is also seen in an equivalent position in the detached skin of the left-hand side of the skull.

Three-dimensional representations of the Dodo generated in Drishti (ANU Vizlab, Australia) have grey values that are mapped using a transform such that the skin appears in a brown tones and the bone in an off-white/yellow colour (Figure 4). In print this is static, but videos are easily created showing the various features [video in the supplementary material]. The skin can be digitally removed to view the entire osteological structure - a possibility that would have been less invasive than dissection and wetting if it had been available to Melville (1848). Similarly, 3D prints can be produced that show only the skeletal elements (Figure 5).

The 3D data were also utilised to calculate the volume of the cranial cavity. Previously this had been attempted by filling the brain cavity with $2.3-2.4 \mathrm{~mm}$ sized lead pellets (Guay, unpublished, in Nowak-Kemp and Hume 2017b). First, the scan was segmented using Avizo 9.4 (Thermofisher) into skin and bone using a seeded watershed method. This identifies each pixel across the image stack as belonging to either the background, skin or bone labels. The cranial cavity is contained within the background pixels but is also attached to other open spaces in the volume through foramina in the base of the neck, near the eyes and canals in the bone for threading nerves and veins. The required volume is extracted by drawing boundaries perpendicular to these openings, whereas the lead ball method would have started to fill openings large enough to accommodate them. With the volume extracted and the pixel size known, the volume of the brain cavity was calculated to be $14.6 \mathrm{~cm}^{3}$. The X-ray scanner had been geometrically calibrated prior to scanning, which reduces inaccuracy in dimensional measurements across the entire volume to as low as 0.3 pixels (Lifton et al. 2013). While no such evaluation has been performed on errors in volume measurement, a realistic geometric error of $\pm 0.25 \mu \mathrm{m}$ in pixel size results in a volume measurement discrepancy of just $0.1 \mathrm{~cm}^{3}$. The greatest source of error in this measurement in fact comes from the relatively subjective determination of the location of the base of the brain.

\section{Embedded gunshot - who killed the Oxford Dodo?}

In the process of generating the CT scans, numerous dark spots were observed on the absorption projections, which are indicative of denser material within the scanning volume. Initially, this was discounted as particulates within the foam in which the specimen was packed for scanning. However, subsequent examination of the individual ortho slices revealed a number of bright white specks associated with star artefacts (Figure 6a, b). The brightness of these indicates material with a particularly high-density contrast in comparison with the biological material, and star artefacts typically appear around metallic objects when the source filter in setup is low. 


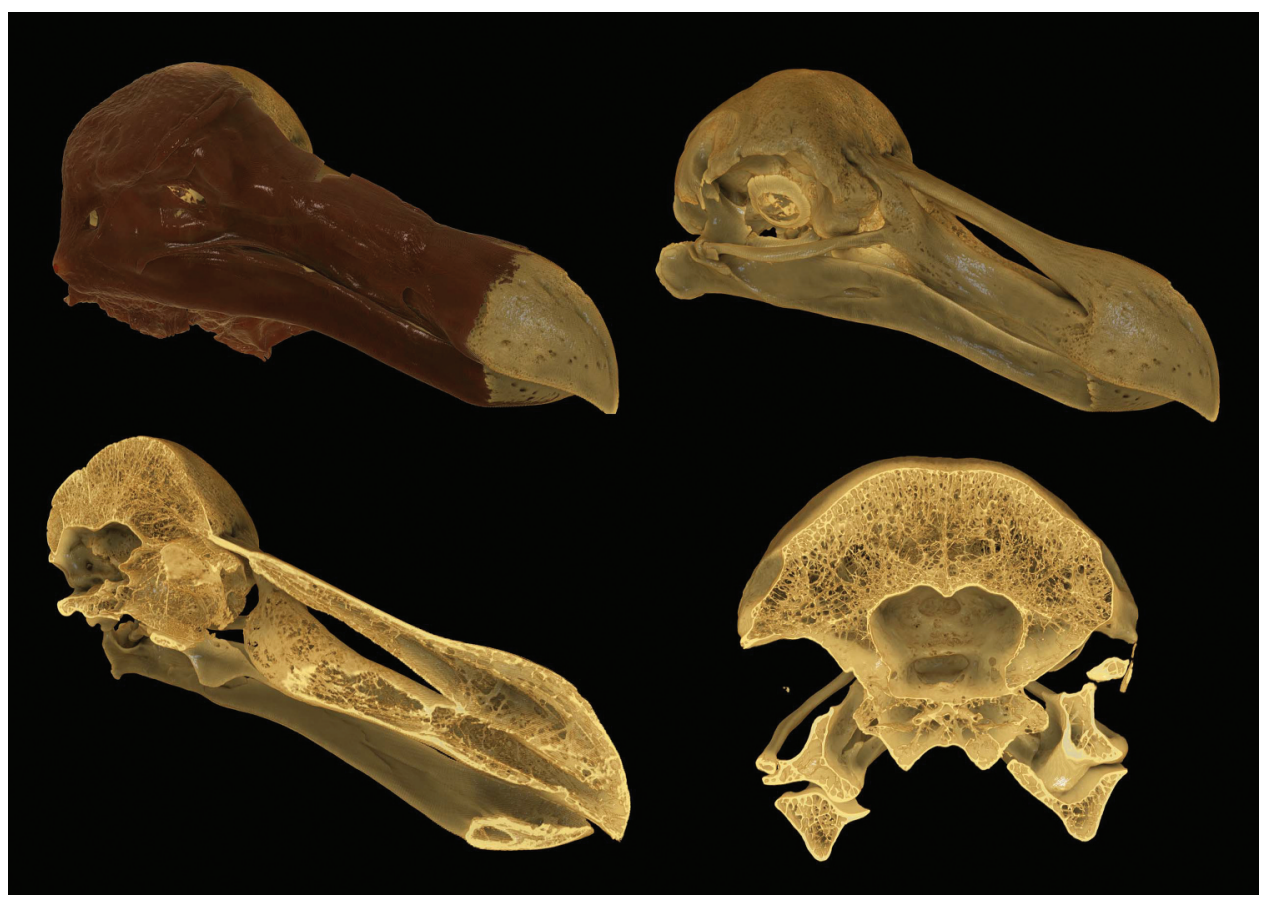

Figure 4. Rendered 3D views of the Oxford Dodo using the X-ray CT data in Drishti. Clockwise from top left: right lateral with skin; right lateral; coronal section through cranial cavity; sagittal section viewed obliquely.

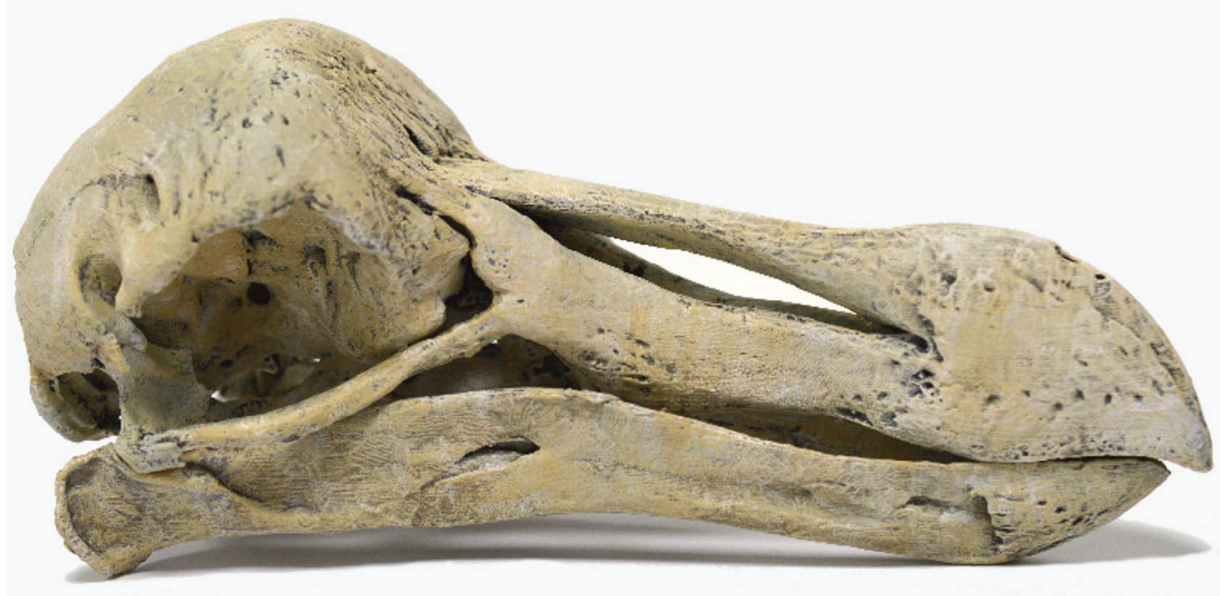

Figure 5. A colour 3D print of the Oxford Dodo skull created by generating a mesh from the X-ray CT data, with the skin of the right-hand side of the skull digitally removed prior to printing.

The segmentation was performed again, but this time seeding the bright areas as a different material. Visualising this in 3D (Figure 6c) showed that the material is dispersed as small particles, with a large concentration embedded within the trabecular bone of the left, posterior side of the skull and six other individual metal particles embedded in the skin. Of those fixed in the skin, three are located within the neck portion of skin, as can be observed in the video, and the remainder are around the right posterior side of the skull. Analysis of the metal particles in segmented scans identified 115 in total, including those embedded in the skin (Figure 6, 7). The equivalent diameters of the particles were calculated by inverting the formula for the volume of a sphere, which demonstrated that only five of the pellets exceeded $1 \mathrm{~mm}$ in diameter (Figure 7).

The size, dispersion and location of the metal particles are consistent with lead gunshot embedded deep within the specimen, which has not previously been mentioned in any descriptions of the material. Although the pellets are concentrated within the left posterior side of the skull, there are no visible entry wounds in the bare bone of the left half of the skull. Instead, the distribution is consistent with the pellets having entered from the right-hand side, and perhaps from beneath the skull, from where they decelerated through the trabecular bone of the skull interior before coming to 


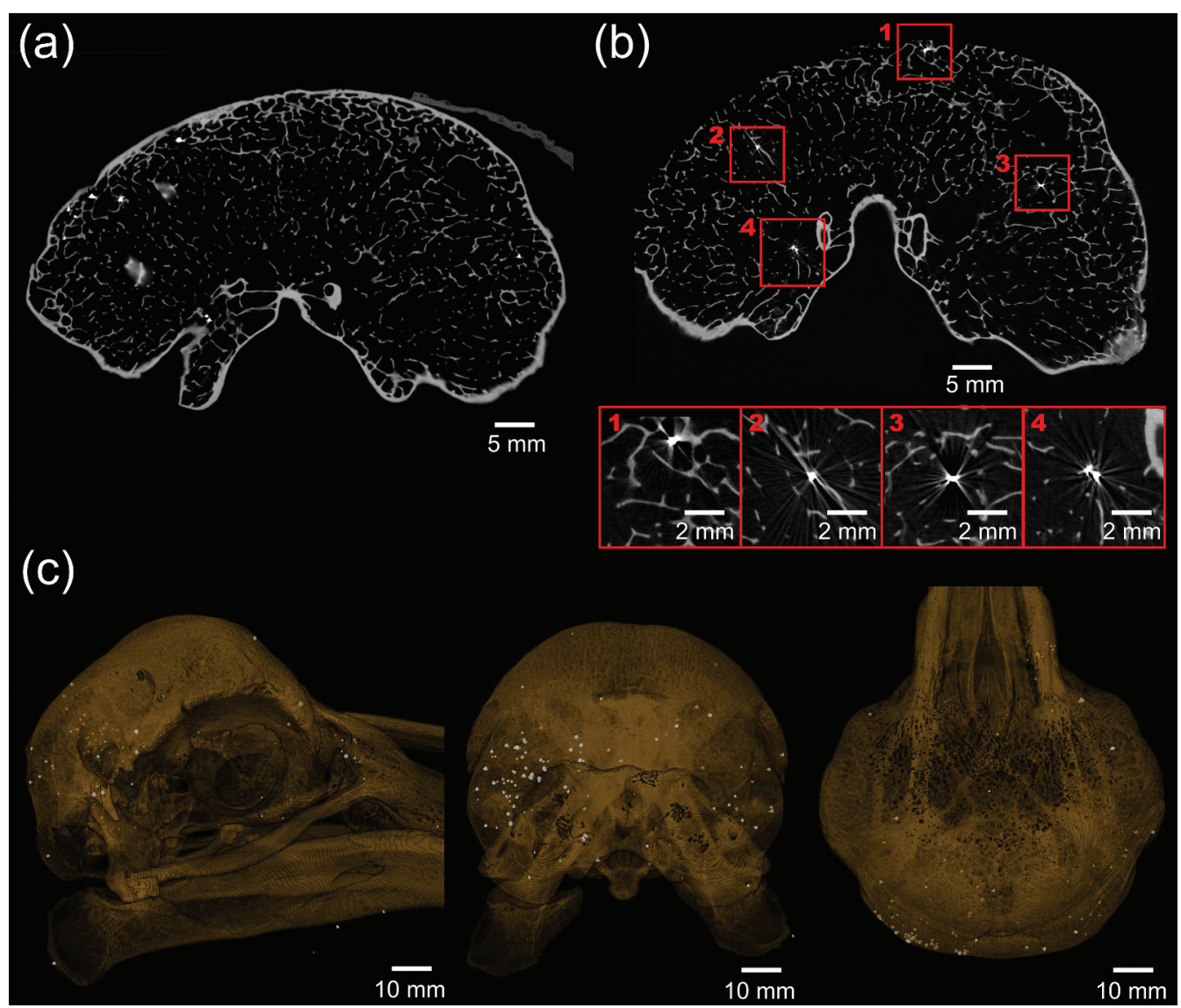

Figure 6. Ortho CT slices and rendered 3D models of the Oxford Dodo showing metal particles, characterised by star artefacts in the ortho slices, embedded within the bone of the skull, including deep within the trabecular bone. The metal particles are concentrated within the bone of the posterior left of the skull. (a) Coronal section through the cranial cavity, viewed from the posterior, with metal particles showing as bright spots; (b) Coronal section farther caudad than (a) showing a number of bright spots highlighted and enlarged to show the star artefacts and their position embedded deeply within trabecular bone; (c) 3D rendered images with the bone transparent and lead shot highlighted in white.

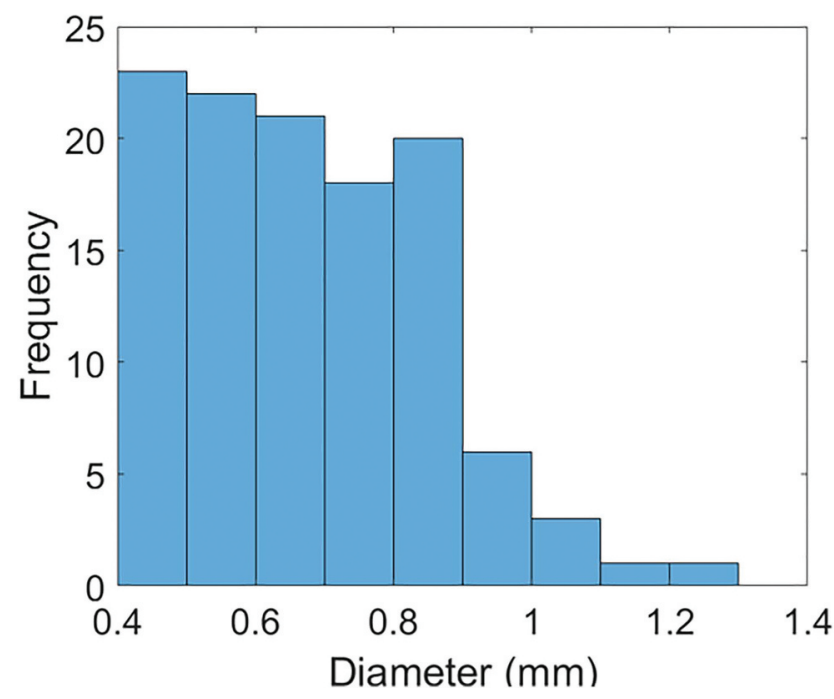

Figure 7. Histogram of the size distribution of metal particles found embedded within the specimen.

rest near the interior surface of the thicker bone that forms the skull roof. Small holes are present in the preserved skin of the right-hand side of the skull and the neck, and these had previously been interpreted as historical insect damage.
The use of firearms for hunting fowl was first mentioned in statutes passed in 1533 during the reign of Henry VIII (Parliament 1533). Up to this time, long bows and cross bows had formed the backbone of English medieval warfare, with the use of guns forbidden without special permission from the King. However, by 1537 the advantages of gunpowder were being recognised through the formation of the Guild of Saint George, later known as the Honourable Artillery Company of London (Highmore 1804). This Royal Charter provided for the limited training and use of handguns for shooting at targets and for the hunting of game and fowl.

At the turn of the seventeenth century the principal personal firearm in use was the matchlock arquebus, with the more advanced matchlock musket not being introduced until around 1660, a date approximately coincident with the last confirmed sighting of the Dodo (Cheke 2015; see above). Both weapons were muzzle-loaded with a smooth unrifled bore and fired a single ball of lead. Hunting by civilians 'filling the pot' was also established within the population and with the emergence of professional wildfowlers looking to catch as many birds as possible. Although there were some statutes relating to the preservation of fowl in England (Ray 1678), none of them mention shooting explicitly. Traditional hunting techniques involved the use of netting and the stalking of sitting birds to as close a range as possible, where the inaccuracy of a small-bore single musket ball could be compensated for (Markham 1621; Folkard 1864). Given their known approachability and 'tameness' when confronted with humans (Parish 2013), the stalking of a Dodo 
would probably have been much easier than approaching European wildfowl.

The practice of hunting with shot evolved to increase efficiency by firing dozens of tiny lead pellets in order to create a pattern of projectiles spread across a wide area (Akehurst 1972). This allowed the shooter to engage with flying targets, preserve the prey by reducing physical damage through the distribution of kinetic energy across a large number of smaller projectiles, and a greater chance of success if shooting at a flock (Markham 1621). Historical records of exactly when this practice was first introduced are very limited with best estimates being sometime during the middle of the seventeenth century (Greener 1910; Gallwey 2011). This makes the discovery of lead shot in the Oxford Dodo significant as it provides direct evidence of shot being used for hunting within the fixed time frame of the existence of the Dodo. The pellets could also represent some of the earliest recorded physical specimens of shot.

The size of the pellets (Figure 7) is important in distinguishing them from the attempts to measure the brain volume using lead shot (Guay, unpublished, in Nowak-Kemp and Hume 2017b) in which size $7.5-8$ lead shot was used $(2.3-2.4 \mathrm{~mm})$ - the pellets identified in the CT scans are less than half that size and they are deeply penetrative into the trabecular bone of the skull. The average diameter of $0.7 \mathrm{~mm}$ is also significantly smaller than shot used for modern fowling, where a minimum 'size 4 ' pellet $(3.05 \mathrm{~mm}$ diameter) is recommended for larger birds such as turkey and geese (Eley Hawk 2019). Early adopters of shooting for fowl were very aware of the impact of shot type and size to have sufficient strength to kill a given size of fowl and to avoid excessive scatter of the shot (Markham 1621; The Gentleman's Recreation 1686). The precision of the shot size and number at this time would have been significantly more varied when compared to modern manufacturing methods. The Gentleman's Recreation (1686) describes a method to make shot where molten lead was dripped through a holed plate of indeterminate size into water, with the advice that the shot should be:

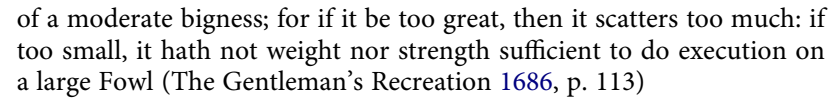

The average number of pellets for a standard modern 12-gauge shotgun using a size 9 shot with a $7 / 8 \mathrm{oz}(24.8 \mathrm{~g})$ load is 515 . The average number of pellets for a .410 shotgun, the smallest commercially available calibre, using a 9 shot with a $7 / 16 \mathrm{oz}(12.4 \mathrm{~g})$ load is 255. Markham (1621) advised that:

\footnotetext{
haile-shot would be of bignesse according to the Game you shoote at which if it be great and large, then it would be of twenty or thirty to a charge, or lesse as the Piece will carry, but if the Game be small, then it would bee of fortie or three-score, as shall seeme best in the discretion of the Fowler (Markham 1621, p. 44)
}

Given the significantly higher number of pellets identified within the skull compared to the probable charge size, this would suggest fragmentation of the shot occurred on impact. Given the specimen age and the frequent wetting and drying of the skin by Cuvier and Melville, it is possible that a number of particles may have been dislodged and expelled from the skull and skin. Regardless, the distribution and quantity of particles found in the head would undoubtedly have been fatal.

\section{Discussion}

The discovery that the Dodo present in the Tradescant, and later Ashmole and Oxford, collections was killed by a gunshot to the the head makes uncertain the presumed link to the live bird seen by Sir Hamon L'Estrange in around 1638. If the L'Estrange Dodo was part of a visitor attraction in London, with a cloth sign advertising the bird hanging outside the building, it seems unlikely that this livelihood would have been ended by a gunshot to the head. NowakKemp and Hume (2017a) noted two other possible provenance routes for the Tradescant Dodo.

The first of these is Emanuel Altham, who visited Mauritius from May to June 1628 as part of his travels on a diplomatic mission to the Persian Court. Whilst on Mauritius he wrote two letters to his brother Edward, in the first of which written on June $18^{\text {th }}$ he said that he was sending him a live Dodo (Newton 1874):

\begin{abstract}
Wee arriued $y^{\mathrm{e}} 28^{\text {th }}$ of may: this Iland hauinge many goates hogs and cowes upon it and very strange fowles called by $\mathrm{y}^{\mathrm{e}}$ portingals DoDo which for rareness of the same and the like beinge not in $y^{\mathrm{e}}$ world but here I have sent you one by $\mathrm{m}^{\mathrm{r}}$ perce: who did arriue with $\mathrm{y}^{\mathrm{e}}$ ship william at this island $\mathrm{y}^{\mathrm{e}} 10^{\text {th }}$ of June. (Newton 1874)
\end{abstract}

In a postscript on the margin of the letter he confirmed the shipping:

Of mr perce you shall receue a iarr of ginger for my sister: some beades for my Cosins your daughters: and a bird called a DoDo. If it liue. (Newton 1874)

The second letter, written on the same day, repeats the description of the first but, unfortunately, as Newton (1874) noted:

Whether this Dodo reached England alive there is nothing to show

The second alternative source is that a Dodo may have been brought to England by Sir Thomas Herbert, who visited Mauritius a year later in 1629 as part of the same diplomatic mission (Newton 1874). Herbert was the first to use the modern form of the name Dodo and estimated the weight of the birds at 50 pounds $(23 \mathrm{~kg})$. He also provided a detailed description:

\begin{abstract}
The halfe of her head is naked seeming couered with a fine vaile, her bill is crooked downwards, in midst is the thrill, from which part to the end tis of a light greene, mixt with a pale yellow tincture; her eyes are small, and like to Diamonds, round and rowling: her clothing downy feathers, her traine three small plumes short and inproportionable, her legs suting to her body, her pounces sharpe, her appetite strong and greedy, Stones and Iron are digested, which description, will better be conceiued in her representation (Herbert 1634, p. 211)
\end{abstract}

It seems not inconceivable that someone with such an eye for anatomical detail would have collected a specimen to bring back to England, but there is no record of this. However, we do have a record that Herbert both knew Tradescant and donated material to the Musæum Tradescantianum. In a letter to Elias Ashmole on 1 September 1680, he wrote:

a place I well know having bin sundry times at Mr. Tradescons (to whom I gave several things I collected on my travails) (Davies 1870; NowakKemp and Hume 2017a)

This is independently confirmed as Herbert is acknowledged as a donor in the list of 'Prinicipall Benefactors' of the collection (Tradescant 1656). Because of this circumstantial evidence, Sir Thomas Herbert was considered to have been a possible source of the Tradescant Dodo by both Duncan (1836) and Gunther (1925), but Hugh Strickland was more sceptical, if not downright dismissive:

I think, however, that had the garrulous Sir Thomas actually killed, skinned, and brought home a Dodo, he would not have failed to record such an exploit in his Travels. Strickland (1848, p. 23)

At this point, however, the trail goes cold. The X-ray CT scanning and $3 \mathrm{D}$ visualisation of the Oxford Dodo have provided us with some certainty about the mode of death of this iconic specimen, as 
well as a wealth of anatomical data, but it has raised more questions than it answers in relation to specimen history and provenance. If it was shot in Mauritius, how was it preserved to enable it to arrive back in England in such good condition? Equally, why would a money-earning visitor attraction in London be despatched with a shot to the head? Without the discovery of new archival material, it is unlikely that the route of the Oxford Dodo into the collection of the Tradescants will ever be known with certainty.

\section{Acknowledgments}

The authors are grateful to Bethany Palumbo for conservation advice and support during transport of the specimen and its mounting for CT scanning. PFW was funded by an EPSRC research studentship and partially funded by Nikon Metrology (grant number 1645325). We are also grateful for detailed, constructive and helpful reviews by Julian Hume and Jolyon Parish.

\section{Disclosure statement}

No potential conflict of interest was reported by the authors.

\section{Funding}

This work was supported by the Engineering and Physical Sciences Research Council [1645325].

\section{ORCID}

J. M. Warnett (iD) http://orcid.org/0000-0003-2284-790X

Mark A. Williams (iD http://orcid.org/0000-0003-3802-7914

Paul F. Wilson (D) http://orcid.org/0000-0002-7243-4372

M. Paul Smith (iD) http://orcid.org/0000-0002-5141-1577

\section{References}

Akehurst R. 1972. Sporting guns. London: Octopus.

Boas FS. 1935. The diary of Thomas Crosfield. London: Oxford University Press. Cheke AS. 2015. Speculation, statistics, facts and the Dodo's extinction date. Hist Biol. 27(5):624-633.

Cheke AS, Parish JC. 2020. The Dodo and the Red Hen, a saga of extinction, misunderstanding, and name transfer: A review. Quaternary. 3(1):4. doi:10.3390/quat3010004.

Clusius C. 1605. Exoticorvm Libri Decem: quibus Animalium, Plantarum, Aromatum, aliorumque peregrinorum Fructuum historiae describuntur. Leiden: Ex Officinâ Plantinianâ Raphelengii.

Das AK. 1973. The Dodo and the Mughals. Hist Today. 23(1):60-63.

Davies R. 1870. A memoir of Sir Thomas Herbert. Yorkshire Arch Top J. 1 (3): $182-214$

Den Hengst J. 2003. The Dodo. The bird that drew the short straw. Marum: Art Revisited.

Duncan PB. 1836. A catalogue of the Ashmolean Museum, descriptive of the zoological specimens, antiquities, coins and miscellaneous curiosities. Oxford: S. Collingwood.

Eley Hawke. 2019. Eley Hawk Shooters Diary. 114th Edition. Sutton Coldfield, UK: Eley Hawk Ltd

Folkard HC. 1864. The Wild-Fowler: A treatise on ancient and modern wildfowling, historical and practical. Second edition ed. London: Longman, Green, Longman and Roberts.

Gallwey RP. 2011. Wildfowl shooting. Containing chapters on: swan and wild geese shooting. UK: Read.

Greener WW. 1910. The gun and its development. 10th ed. London: Cassell and Company Ltd.

Gunther RT. 1925. Early science in Oxford. Vol III. Pt. I The biological sciences, Pt II. The biological collections. Oxford: privately published.

Herbert T. 1634. A relation of some yeares travaile, begunne anno 1626. London: William Stansby and Jacob Bloome.
Highmore. 1804. The history of the Honourable Artillery Company of the City of London, from its earliest annals to the peace of 1802. London:privately published.

Hume JP. 2006. The history of the dodo Raphus cucullatus and the penguin of Mauritius. Hist Biol. 18(2):65-89. doi:10.1080/08912960600639400.

Hume JP, Cheke AS. 2004. The white Dodo of Réunion island: unravelling a scientific and historical myth. Arch Nat Hist. 31(1):57-79. doi:10.3366/ anh.2004.31.1.57.

Hume JP, Winters R. 2016. Captive birds on Dutch Mauritius: bad-tempered parrots, warty pigeons and notes on other native animals. Hist Biol. 28 (6):812-822. doi:10.1080/08912963.2015.1036750.

Ivanov I. 1958. An Indian picture of the Dodo. J Ornithol. 99:438-440. doi:10.1007/BF01671614.

Jackson A. 2013. Added credence for a late dodo extinction date. Hist Biol. 26 (6):699-701. doi:10.1080/08912963.2013.838231.

Lhwyd E. 1695-1696. Liber domini Vice-Cancellarii [The vice-chancellor's consolidated catalogue of all collections]. Manuscript catalogue of zoological specimens. Oxford: Ashmolean Museum Catalogue AMS 11.

Lifton JJ, Malcom AA, McBride JW, Cross KJ 2013. The application of voxel size correction in X-ray computed tomography for dimensional metrology. Singapore international NDT conference and exhibition 2013, Singapore.

Markham G. 1621. Hungers Prevention: or, The whole Arte of Fowling by Water and Land. London: Printed by A. Math. for Anne Helme and Thomas Langley.

Melville AG. 1848. Osteology of the Dodo and Solitaire. In: Strickland HE and Melville AG. 1848. The dodo and its kindred; or, The history, affinities, and osteology of the dodo, solitaire, and other extinct birds of the islands Mauritius, Rodriguez, and Bourbon. London: Reeve, Benham, and Reeve; p. 67-134.

Morel A. 1778. Sur les oiseaux monstrueux nommés Dronte, Dodo, Cygne capuchoné, Solitaire \& Oiseau de Nazare \& sur la petite isle de sable à 50 lieues environ de Madagascar. Obs Phys Nat Arts Paris. 12:154-157.

Newton A. 1874. On a living Dodo shipped for England in the year 1628. Proc Zoo Soc Lond. 307:447-449.

Nowak-Kemp M, Hume JP. 2017a. The Oxford Dodo. Part 1: the museum history of the Tradescant Dodo: ownership, displays and audience. Hist Biol. 29(2):234-247. doi:10.1080/08912963.2016.1152471.

Nowak-Kemp M, Hume JP. 2017b. The Oxford Dodo. Part 2: from curiosity to icon and its role in displays, education and research. Hist Biol. 29(3):296-307. doi:10.1080/08912963.2016.1155211.

Owen R. 1867. On the Osteology of the Dodo (Didus ineptus, Linn.). Trans Zool Soc Lon. 6(2):49-85.

Parish JC. 2013. The Dodo and the Solitaire. A natural history. Bloomington \& Indianapolis: Indiana University Press.

Parliament. 1533. 25 Hen. 8. c. 17. An act for shooting in cross bows and hand guns. England, UK.

Ray J. 1678. The ornithology of Francis Willughby of Middleton in the county of Warwick Esq, fellow of the Royal Society. In three books. Wherein all the birds hitherto known, being reduced into a method sutable to their natures, are accurately described. The descriptions illustrated by most elegant figures, nearly resembling the live birds, engraven in LXXVIII copper plates. Translated into English, and enlarged with many additions throughout the whole work: to which are added, Three considerable discourses, I. of the art of fowling, with a description of several nets in two large copper plates. II. of the ordering of singing birds. III. of falconry. London: Printed by A. C. for John Martyn, Printer to the Royal Society at the Bell in St. Pauls Church-Yard.

Roberts DL. 2013. Refuge-effect hypothesis and the demise of the dodo. Conserv Biol. 27:1478-1480. doi:10.1111/cobi.12134.

Strickland HE. 1848. History and external characters of the Dodo, Solitaire, and other Brevipennate birds of Mauritius, Rodriguez, and Bourbon. In: Strickland HE, Melville AG. 1848. The dodo and its kindred; or, The history, affinities, and osteology of the dodo, solitaire, and other extinct birds of the islands Mauritius, Rodriguez, and Bourbon. London: Reeve, Benham, and Reeve; p. 1-65.

Temple RC. editor, 1919. The travels of Peter Mundy, in Europe and Asia,1608-1667. Vol. III, London: Hakluyt Society.

The Gentleman's Recreation. 1686. The Gentleman's Recreation: in four parts, viz. hunting, fowling, hawking, fishing. London:Printed by Freeman Collins, for Nicholas Cox

Tradescant J. 1656. Musæum Tradescantianum, or, A collection of rarities, preserved at South-Lambeth neer London. London: John Grismond.

Wilkin S. ed.. 1835-1836. Sir Thomas Browne's works: including his life and correspondence. 2 vols. London: William Pickering; Norwich: Josiah Fletcher

Winters R, Hume JP. 2015. The dodo, the deer and a 1647 voyage to Japan. Hist Biol. 27(2):258-264. doi:10.1080/08912963.2014.884566. 